\title{
Correlation of the Pathogenic Bacteria Isolated from Sputum Samples with Age, Sex, Seasonal Variation and Determination of Their Antibiotic Resistance Pattern
}

\author{
Tasnia Ahmed ${ }^{1 *}$ iD , Tanjina Islam ${ }^{1}$, Raquiba Sultana Soha, Eiva Akter $^{1}$
}

1. Department of Microbiology, Stamford University Bangladesh

10.30699/ijmm.15.6.700

\begin{abstract}
Background and Aim: In the current study, the relevance of the respiratory infection with the age, sex, and seasonal variation of the year were studied side by side with the determination of the responsible bacterial pathogen and their antibiotic sensitivity patterns.
\end{abstract}

Materials and Methods: One hundred sputum samples were collected to determine the causative bacteria of respiratory distress. An antibiotic susceptibility test was done to determine the susceptibility pattern of the isolates.

Results \& Conclusion: The study found six distinct bacteria causing respiratory infections (Pseudomonas spp., Klebsiella spp., Acinetobacter spp., Enterobacter spp. Escherichia coli, and Serratia spp.). Out of 100 isolates, 21 isolates were susceptible to all of the fourteen antibiotics used in the study, and 4 isolates were completely resistant towards all of the antibiotics which were used in the study. The choice of antibiotic was based on the most prescribed medicines given by the doctors of Bangladesh.

Keywords: Age, Antibiotic resistance, Bacterial infection, Gender, Respiratory tract infections

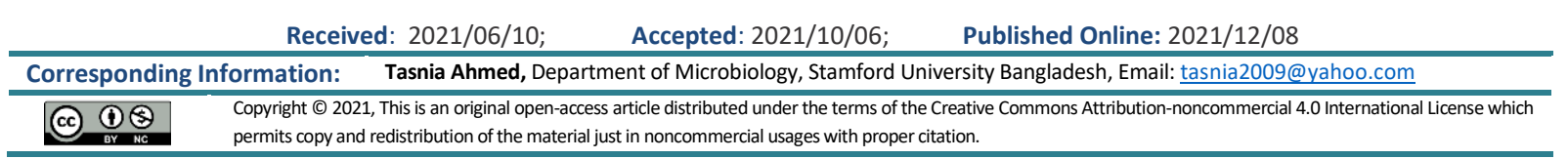

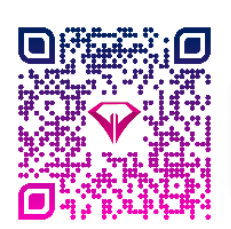

Use your device to scan and read the article online

Ahmed T, Islam T, Sultana Soha R, Akter E. Correlation of the Pathogenic Bacteria Isolated from Sputum Samples with Age, Sex, Seasonal Variation and Determination of Their Antibiotic Resistance Pattern. Iran J Med Microbiol. 2021; 15 (6): :700-707

Download citation: BibTeX | RIS | EndNote | Medlars | ProCite | Reference Manager | RefWorks Send citation to: $\otimes$ Mendeley 2 zotero $\mathbb{H}_{\text {RefWorks }}$

\section{Introduction}

Respiratory tract infections are one of the most commonly occurred health conditions $(5 \%$ to $10 \%$ death reported in $\mathrm{CDC}$ ) in the community and this scenario prevails over the year regardless of the country. Pneumonia is such a respiratory disease (1). Some of the most commonly found bacteria causing lower respiratory tract infections include: Streptococcus pneumoniae, Mycoplasma pneumonia, Legionella pneumophila, Staphylococcus aureus, Haemophilus influenza, Klebsiella pneumoniae, Coxiella burnetii, etc. $(2,3)$. Some viruses causing such infections include human coronavirus, adenovirus, parainfluenza virus 1 , and 3 , influenza virus $A$ and $B$, respiratory syncytial virus, and so on $(4,5)$. Fungal species like Aspergillus spp., Cladosporium spp., Alternaria spp.,
Penicillium spp., Fusarium spp. $(6,7)$ and protozoa like Legionella pneumophilia, Chlamydia pneumoniae, and Francisella tularensis (8-10). Usually, the lower respiratory tract is microbes free, but they can enter at any time if they can defeat the host immune system. Generally, they (normal flora and the infectious microbes) find their way from anatomically adjacent areas (19). Some predisposing factors of respiratory infections include immunosuppression, smoking, inhalation therapy, alcoholism, liver disease, diabetes, overweight, asthma, cardiovascular disease, dementia, cancer, immunodeficiency (12).

Antibiotic resistance of pathogenic bacteria has become a common scenario. Resistance can be 
acquired by selective pressure, production of biofilm, efflux mechanism, synthesis of drug degrading enzymes, and resistance gene acquisition by plasmid $(13,14)$. In Bangladesh, resistance is more common due to the uncontrolled use of antibiotics. In previous studies, it has been reported that vancomycin susceptibility of enterococci was $100 \%$ (median value). The most common etiologic agent of UTI was Escherichia coli showing $94.6 \%$ median resistance to ampicillin. Staphylococcus aureus showed resistance to penicillin in $89.7 \%$ of cases (15).

The current study aimed to investigate the presence of bacteria in the sputum of patients suffering from lower respiratory tract diseases and determine their antibiotic drug resistance pattern.

\section{Material and Methods}

\section{Study Area and Sampling}

One hundred sputum samples were collected from the outdoor patients of Comilla Diabetic Hospital who resided in Cumilla city during five different months (July-2019, August-2019, September-2019, February2020, and March-2020). No specific criteria were set while collecting the samples. Verbal permission from the patients was ensured before sampling.

\section{Isolation of Bacteria}

The samples were further subjected to inoculation onto different media (blood agar for hemolytic bacteria, i.e., gamma hemolytic Enterobacter spp., chocolate agar for Serratia spp., and MacConkey agar for Pseudomonas spp., Klebsiella spp., Escherichia coli). After incubation at $37^{\circ} \mathrm{C}$ for 24 hours, culture plates were observed for the presence of discrete colonies and subjected to biochemical identification. Some biochemical tests were catalase, oxidase, indole production test, triple-sugar iron agar test, citrate utilization test, motility test, red methyl production, and Voges- Proskauer test (16).

\section{Determination of Antibiotic Susceptibility}

Fourteen commonly prescribed antibiotics were selected to demonstrate the antibiotic drug resistance pattern of the isolated bacteria. Meropenem (IMP,

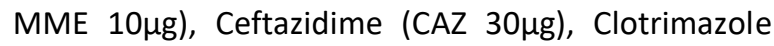
(TS,COT $30 \mu \mathrm{g}$ ), Ciprofloxacin (CIP $5 \mu \mathrm{g}$ ), Gentamycin (GN $10 \mu \mathrm{g}$ ), Netilmycin (NET $10 \mu \mathrm{g}$ ), Amikacin (AK 30 $\mu \mathrm{g})$, Cefixime (CFM $30 \mu \mathrm{g})$, Cefotaxime (CTX $30 \mu \mathrm{g}$ ), Astrenam (ATM $10 \mu \mathrm{g}$ ), Piperacillin (PTZ, PIT $30 \mu \mathrm{g}$ ), Colistin (CO,CL $30 \mu \mathrm{g}$ ), Amoxi-clav (AUG, AMC $30 \mu \mathrm{g}$ ), Ceftriaxone (CRO $30 \mu \mathrm{g}$ ). This study followed Kirby Bauer's disc diffusion method (17). The zone sizes were measured and determined the strains as sensitive or resistant, using CLSI guidelines, 2020 (18).

\section{Statistica Analysis}

The test was performed to determine the t-values from the percentages of antibiotic resistance and susceptibility. The confidence level of the t-test was also selected for the determination of the appropriateness of the data.

\section{Results \& Discussion}

The rate of infection was higher for women during July 2019 (18 cases), September 2019 (13 cases), and March 2020 (12 cases) than their male counterparts. August 2019 (19 cases) and February 2020 (11 cases) showed only male patients (Figure 1).

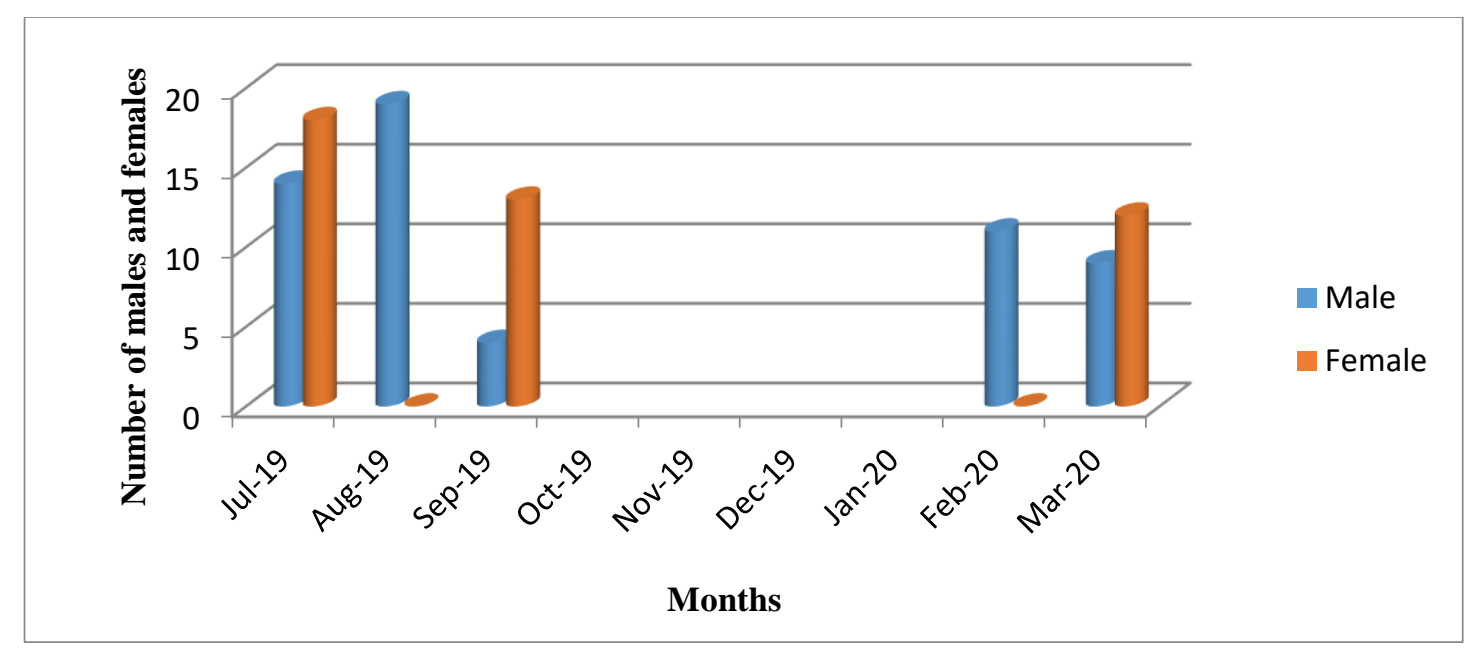

Figure 1. Number of infected males and females in five different months of the year.

During the study, we found six different isolates (Acinetobacter spp., Pseudomonas spp., Klebsiella spp., Enterobacter spp., Escherichia coli, and Serratia spp.) (Figure 2). 


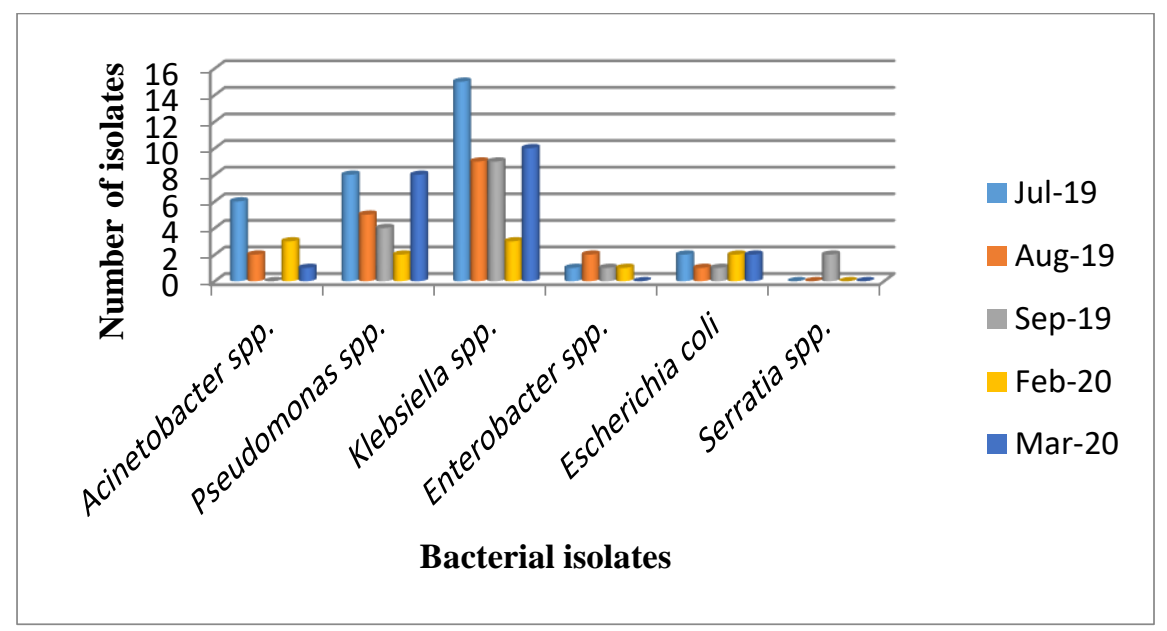

Figure 2. The occurrence of different bacteria in five different months of the year.

Lower respiratory tract infection incidents showed a similar pattern in both male and female patients for different age groups (Figure 3 ).

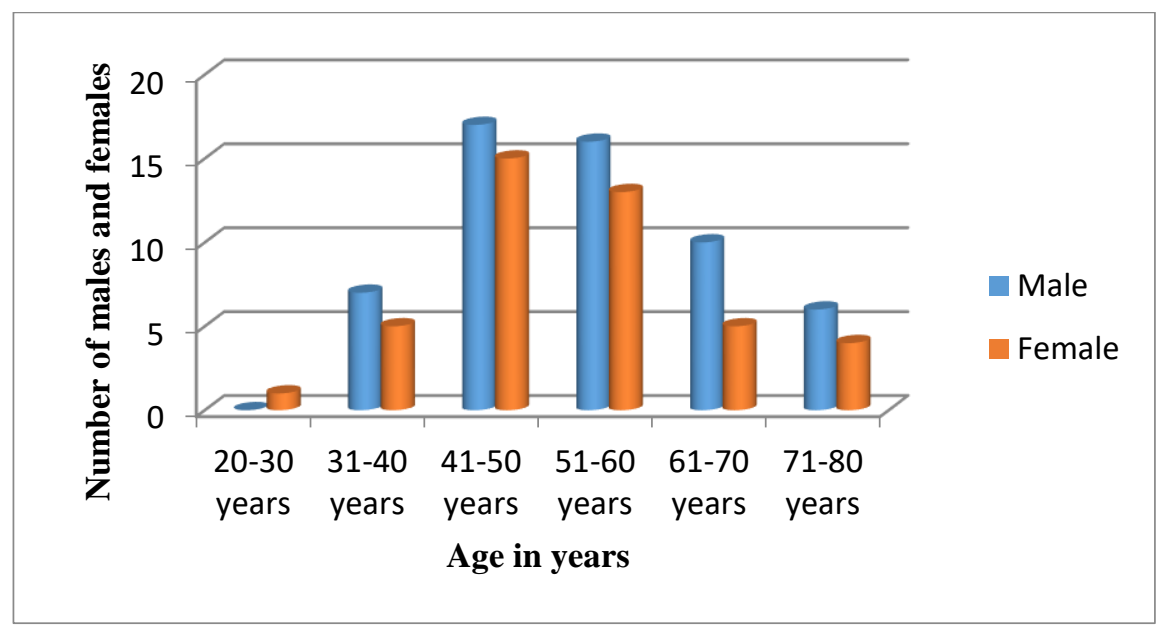

Figure 3. Rate of infection among different ages.

Figure 4 clearly demonstrates that Klebsiella spp. and Pseudomonas spp. were the most frequent in the age group of 41-50 years. Escherichia coli occurred at a higher rate at 61-70 years of age. Acinetobacter spp. was the most occurring infectious agent in the 51-60 years age group.

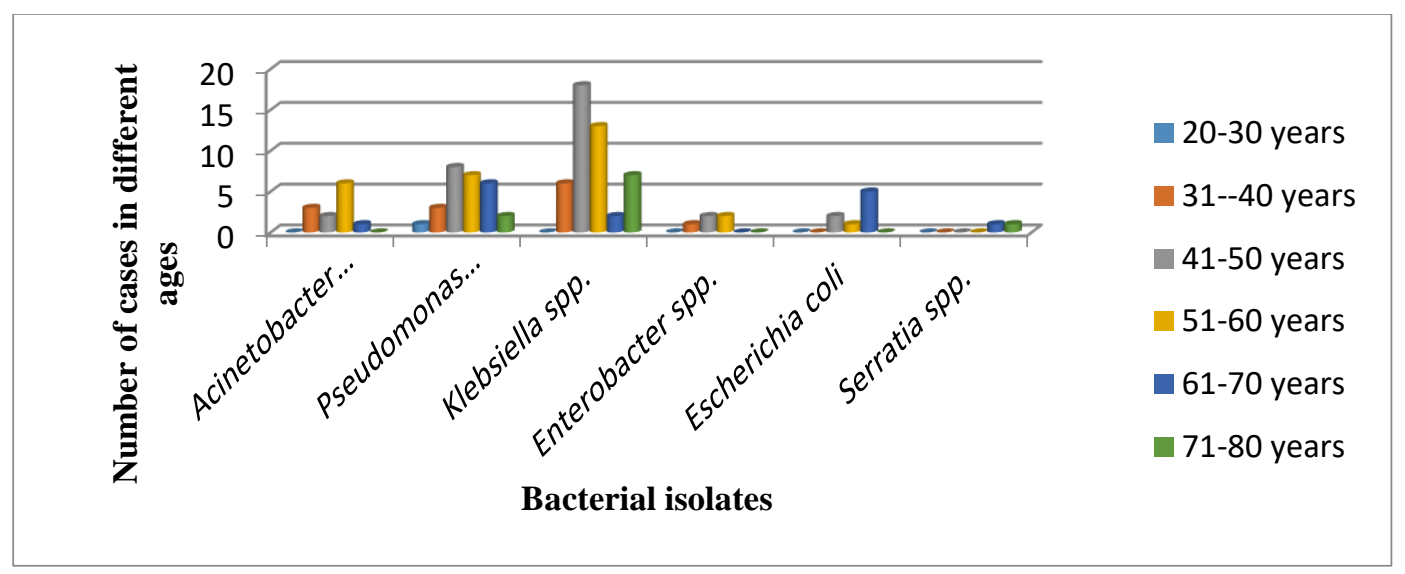

Figure 4. Frequency of bacterial infection among different age groups. 
Total fourteen antibiotics were used to determine the antibiotic sensitivity of each bacterial strain isolated from the one hundred patients with lower respiratory disease symptoms. Among 100 samples, six isolates were found, like Acinetobacter spp. ( $n-=12)$, Enterobacter spp. $(n=5)$, Escherichia coli $(n=8)$, Klebsiella spp. ( $n=46)$, Pseudomonas spp. $(n=27)$ and Serratia spp. $(n=2)$. T-value for each antibiotic against the resistance and sensitivity pattern of all the isolates were determined. Lowest $t$-value was found for meropenem and gentamycin $(0.0006815,95 \% \mathrm{CL}=$ 0.0027 ) and highest $t$-value was found for astrenam (0.4833245, 95\% CL= 0.0025).

Table 1. Antibiotic resistance of the isolates collected from 100 patients

\begin{tabular}{|c|c|c|c|c|c|c|c|c|c|c|c|c|c|c|c|}
\hline \multirow[t]{2}{*}{$\begin{array}{l}\dot{0} \\
z \\
\frac{\pi}{0} \\
\frac{\pi}{0}\end{array}$} & \multirow[t]{2}{*}{$\begin{array}{c}\text { Bacteri } \\
\text { a }\end{array}$} & \multicolumn{2}{|c|}{$\begin{array}{c}\text { Meropenem } \\
\text { t-value: } \\
0.0006815 \\
95 \% \mathrm{CL}= \\
0.0027\end{array}$} & \multicolumn{2}{|c|}{$\begin{array}{c}\text { Ceftazidime } \\
\text { t-value: } \\
0.1367741 \\
95 \% \mathrm{CL}= \\
0.0026\end{array}$} & \multicolumn{2}{|c|}{$\begin{array}{c}\text { Cotrimazol } \\
\text { e } \\
\text { t-value } \\
0.4324532 \\
95 \% \mathrm{CL}= \\
0.0021\end{array}$} & \multicolumn{2}{|c|}{$\begin{array}{c}\text { Ciprofloxaci } \\
\mathbf{n} \\
\text { t-value: } \\
0.1874698 \\
95 \% \mathrm{CL}= \\
.001802\end{array}$} & \multicolumn{2}{|c|}{$\begin{array}{c}\text { Gentamyci } \\
\text { n } \\
\text { t-value: } \\
0.0006815 \\
95 \% \mathrm{CL}= \\
0.0027\end{array}$} & \multicolumn{2}{|c|}{$\begin{array}{c}\text { Netilmycin } \\
\text { t-value: } \\
0.0007252 \\
95 \% \mathrm{CL}= \\
0.0026\end{array}$} & \multicolumn{2}{|c|}{$\begin{array}{c}\text { Amikacin } \\
\text { t-value } \\
0.0599497 \\
95 \% \mathrm{CL}= \\
0.0020\end{array}$} \\
\hline & & $\mathbf{R}$ & $S$ & $\mathbf{R}$ & S & $\mathbf{R}$ & S & $\mathbf{R}$ & $S$ & $\mathbf{R}$ & S & $\mathbf{R}$ & $S$ & $\mathbf{R}$ & S \\
\hline 1 & $\begin{array}{c}\text { Acinetob } \\
\text { acter } \\
\text { spp. } \\
(n=12)\end{array}$ & $\begin{array}{c}33.3 \\
4 \%\end{array}$ & $66.66 \%$ & $\begin{array}{c}100 \\
\%\end{array}$ & $0 \%$ & $\begin{array}{c}66.67 \\
\%\end{array}$ & $\begin{array}{c}33.33 \\
\%\end{array}$ & $\begin{array}{c}33.33 \\
\%\end{array}$ & $\begin{array}{c}66.67 \\
\%\end{array}$ & $\begin{array}{c}33.34 \\
\%\end{array}$ & $\begin{array}{c}66.66 \\
\%\end{array}$ & $\begin{array}{c}33.34 \\
\%\end{array}$ & $\begin{array}{c}66.66 \\
\%\end{array}$ & $\begin{array}{c}91.67 \\
\%\end{array}$ & $\begin{array}{c}8.33 \\
\%\end{array}$ \\
\hline 2 & $\begin{array}{c}\text { Enteroba } \\
\text { cter } \\
\text { spp. }(n=5)\end{array}$ & $0 \%$ & $100 \%$ & $0 \%$ & $100 \%$ & $40 \%$ & $60 \%$ & $40 \%$ & $60 \%$ & $0 \%$ & $100 \%$ & $0 \%$ & $100 \%$ & $0 \%$ & $100 \%$ \\
\hline 3 & $\begin{array}{c}\text { Escherich } \\
\text { ia coli } \\
(n=8)\end{array}$ & $25 \%$ & $75 \%$ & $\begin{array}{c}37.5 \\
\%\end{array}$ & $62.5 \%$ & $\begin{array}{c}87.5 \\
\%\end{array}$ & $\begin{array}{c}12.5 \\
\%\end{array}$ & 100 & $0 \%$ & $25 \%$ & $75 \%$ & $25 \%$ & $75 \%$ & $25 \%$ & $75 \%$ \\
\hline 4 & $\begin{array}{c}\text { Klebsiella } \\
\text { spp. } \\
(n=46)\end{array}$ & $\begin{array}{c}13.0 \\
4 \%\end{array}$ & $86.96 \%$ & $\begin{array}{c}39.5 \\
8 \%\end{array}$ & $60.42 \%$ & $\begin{array}{c}32.60 \\
\%\end{array}$ & $\begin{array}{c}67.4 \\
\%\end{array}$ & $\begin{array}{c}36.95 \\
\%\end{array}$ & $\begin{array}{c}63.05 \\
\%\end{array}$ & $\begin{array}{c}13.04 \\
\%\end{array}$ & $\begin{array}{c}86.96 \\
\%\end{array}$ & $\begin{array}{c}15.21 \\
\%\end{array}$ & $\begin{array}{c}84.79 \\
\%\end{array}$ & $\begin{array}{c}13.04 \\
\%\end{array}$ & $\begin{array}{c}86.96 \\
\%\end{array}$ \\
\hline 5 & $\begin{array}{c}\text { Pseudom } \\
\text { onas spp. } \\
(n=27)\end{array}$ & $0 \%$ & $100 \%$ & $7.4 \%$ & $92.6 \%$ & $\begin{array}{c}88.46 \\
\%\end{array}$ & $\begin{array}{c}11.54 \\
\%\end{array}$ & $\begin{array}{c}29.62 \\
\%\end{array}$ & $\begin{array}{c}70.38 \\
\%\end{array}$ & $0 \%$ & $100 \%$ & $0 \%$ & $100 \%$ & $\begin{array}{c}11.11 \\
\%\end{array}$ & $\begin{array}{c}88.89 \\
\%\end{array}$ \\
\hline 6 & $\begin{array}{c}\text { Serratia } \\
\text { spp. } \\
(n=2)\end{array}$ & $0 \%$ & $100 \%$ & $0 \%$ & $100 \%$ & $0 \%$ & $100 \%$ & $0 \%$ & $100 \%$ & $0 \%$ & $100 \%$ & $0 \%$ & $100 \%$ & $0 \%$ & $100 \%$ \\
\hline $\begin{array}{l}\sum_{2}^{0} \\
\stackrel{0}{0} \\
\frac{\pi}{0}\end{array}$ & Bacteria & $\begin{array}{r}\text { Cef } \\
t-v \\
0.39 \\
95 \% \mathrm{CL}\end{array}$ & $\begin{array}{l}\text { xime } \\
\text { lue: } \\
3647 \\
=0.0027\end{array}$ & $\begin{array}{r}\text { Cefot } \\
\text { t-va } \\
0.327 \\
95 \% \mathrm{CL}=\end{array}$ & $\begin{array}{l}\text { axime } \\
\text { lue: } \\
8051 \\
=0.0029\end{array}$ & $\begin{array}{r}\text { Ast } \\
t-v \\
0.48 \\
95 \\
0 .\end{array}$ & $\begin{array}{l}\text { nam } \\
\text { ue: } \\
3245 \\
C L= \\
25\end{array}$ & $\begin{array}{r}\text { Pipe } \\
\mathrm{t}-\mathrm{y} \\
0.0 \\
95 \% \mathrm{C}\end{array}$ & $\begin{array}{l}\text { cillin } \\
\text { ue: } \\
3710 \\
0.0023\end{array}$ & $\begin{array}{r}\mathrm{Co} \\
\mathrm{t}-\mathrm{v} \\
0.00 \\
95 \\
0 .\end{array}$ & $\begin{array}{l}\text { tin } \\
\text { ue: } \\
9787 \\
C L= \\
24\end{array}$ & $\begin{array}{r}\text { Am } \\
\mathrm{t}-\mathrm{v} \\
0.2 \\
95 \\
0 .\end{array}$ & $\begin{array}{l}\text { iclav } \\
\text { ue: } \\
937 \\
\mathrm{CL}= \\
17\end{array}$ & $\begin{array}{r}\text { Ceft } \\
\mathrm{t}- \\
0.1 \\
95 \% \mathrm{C}\end{array}$ & $\begin{array}{l}\text { xone } \\
\text { le: } \\
459 \\
0.0025\end{array}$ \\
\hline & & $\mathrm{R}$ & $S$ & $\mathrm{R}$ & S & $R$ & $S$ & $\mathrm{R}$ & $S$ & $\mathrm{R}$ & S & $\mathrm{R}$ & S & $\mathrm{R}$ & S \\
\hline 1 & $\begin{array}{c}\text { Acinetob } \\
\text { acter } \\
\text { spp. } \\
(n=12)\end{array}$ & $100 \%$ & $0 \%$ & $100 \%$ & $0 \%$ & $100 \%$ & $0 \%$ & $75 \%$ & $25 \%$ & $0 \%$ & $100 \%$ & $75 \%$ & $25 \%$ & $100 \%$ & $0 \%$ \\
\hline 2 & $\begin{array}{c}\text { Enteroba } \\
\text { cter } \\
\text { spp. }(n=5)\end{array}$ & $20 \%$ & $80 \%$ & $0 \%$ & $\begin{array}{c}100 \\
\%\end{array}$ & $0 \%$ & $100 \%$ & $20 \%$ & $80 \%$ & $40 \%$ & $60 \%$ & $60 \%$ & $40 \%$ & $0 \%$ & $100 \%$ \\
\hline 3 & $\begin{array}{c}\text { Escherich } \\
\text { ia coli } \\
(n=8)\end{array}$ & $100 \%$ & $0 \%$ & $100 \%$ & $0 \%$ & $100 \%$ & $0 \%$ & $25 \%$ & $75 \%$ & $0 \%$ & $100 \%$ & $\begin{array}{c}37.5 \\
\%\end{array}$ & $\begin{array}{c}62.5 \\
\%\end{array}$ & $37.5 \%$ & $62.5 \%$ \\
\hline 4 & $\begin{array}{c}\text { Klebsiella } \\
\text { spp. } \\
(n=46)\end{array}$ & $43.47 \%$ & $\begin{array}{c}56.53 \\
\%\end{array}$ & $43.47 \%$ & $\begin{array}{c}56.5 \\
3 \%\end{array}$ & $\begin{array}{c}43.47 \\
\%\end{array}$ & $\begin{array}{c}56.53 \\
\%\end{array}$ & $\begin{array}{c}13.04 \\
\%\end{array}$ & $\begin{array}{c}86.96 \\
\%\end{array}$ & $\begin{array}{c}15.21 \\
\%\end{array}$ & $\begin{array}{c}84.79 \\
\%\end{array}$ & $\begin{array}{c}56.52 \\
\%\end{array}$ & $\begin{array}{c}43.48 \\
\%\end{array}$ & $\begin{array}{c}43.47 \\
\%\end{array}$ & $\begin{array}{c}56.53 \\
\%\end{array}$ \\
\hline 5 & $\begin{array}{c}\text { Pseudom } \\
\text { onas spp. } \\
(n=27)\end{array}$ & $3.7 \%$ & $\begin{array}{c}96.3 \\
\%\end{array}$ & $11.11 \%$ & $\begin{array}{c}88.8 \\
9 \%\end{array}$ & $\begin{array}{c}11.11 \\
\%\end{array}$ & $\begin{array}{c}88.89 \\
\%\end{array}$ & $\begin{array}{c}11.11 \\
\%\end{array}$ & $\begin{array}{c}88.89 \\
\%\end{array}$ & $\begin{array}{c}11.11 \\
\%\end{array}$ & $\begin{array}{c}88.89 \\
\%\end{array}$ & $\begin{array}{c}22.22 \\
\%\end{array}$ & $\begin{array}{c}77.78 \\
\%\end{array}$ & $\begin{array}{c}14.81 \\
\%\end{array}$ & $\begin{array}{c}85.19 \\
\%\end{array}$ \\
\hline 6 & $\begin{array}{c}\text { Serratia } \\
\text { spp. } \\
(n=2)\end{array}$ & $0 \%$ & $100 \%$ & $100 \%$ & $0 \%$ & $50 \%$ & $50 \%$ & $0 \%$ & $100 \%$ & $50 \%$ & $50 \%$ & $100 \%$ & $0 \%$ & $0 \%$ & $100 \%$ \\
\hline
\end{tabular}

$\mathrm{n}=$ isolate number, $\mathrm{CL}=$ confidence level, $\mathrm{R}=$ resistance, $\mathrm{S}=$ sensitive 
Table 2. Prevalence of multidrug-resistant isolates.

\begin{tabular}{|c|c|c|}
\hline Acinetobacter spp. $(n=12)$ & Five (5) and above- 12 isolates & None \\
\hline Pseudomonas spp. $(n=27)$ & $\begin{array}{c}\text { One (1)- } 11 \text { isolates } \\
\text { Two (2)- } 7 \text { isolates } \\
\text { Three (3)- } 3 \text { isolates } \\
\text { Five (5) and above- } 2 \text { isolates }\end{array}$ & 4 isolates \\
\hline Klebsiella spp. $(n=46)$ & $\begin{array}{c}\text { One (1)- } 6 \text { isolates } \\
\text { Five (5) and above- } 20 \text { isolates }\end{array}$ & 20 isolates \\
\hline Enterobacter spp. $(n=5)$ & $\begin{array}{l}\text { One (1)- } 1 \text { isolate } \\
\text { Two (2)- } 2 \text { isolates }\end{array}$ & 2 isolates \\
\hline Escherichia coli $(n=8)$ & Five (5) and above- 8 isolates & None \\
\hline Serratia spp. $(n=2)$ & $\begin{array}{l}\text { One (1)- } 1 \text { isolate } \\
\text { Two (2)- } 1 \text { isolate }\end{array}$ & None \\
\hline
\end{tabular}

All of the Acinetobacter spp. (12 isolates) and E. coli (8 isolates) showed resistance to at least five antibiotics (Table 2). Pseudomonas spp. isolates showed various outcomes with each isolate. For example, out of 27 isolates, 11 were resistant to one antibiotic, 7 isolates to two antibiotics, 3 isolates to three antibiotics, and 2 were resistant to five or more antibiotics. Others were completely susceptible to the used antibiotics. The highest number of pathogenic bacteria present was Klebsiella spp. $(n=46)$, of which, 6 were resistant to only one antibiotic, and 20 were resistant to five or more antibiotics. Enterobacter spp. (3 isolates) and Serratia spp. (2 isolates) showed the least resistance to antibiotics (one or two antibiotics only) compared to other bacterial isolates.

The correlation of respiratory tract infection showed a high prevalence of infection among men during August 2019 and March 2019. Women were more infected in July 2019, September 2019, and March 2020. The data might be different based on the number of outdoor patients visiting the different hospitals during the same period (Figure 1). In previous studies, that males were more prone to respiratory diseases than females due to sex-specific immunity differences like neutrophil activity, cytokine production, the activity of steroid hormones (19).

Except for Enterobacter spp., all other isolates showed a higher number of infections in July 2019 (Figure 2). Serratia spp. was only present in September 2019 as this is one of the less common pathogens to cause disease. September 2019 (17 cases) and February 2020 (11 cases) showed the lowest respiratory infections. In another study, the highest bacterial respiratory infection was recorded during January, August, and September (20).

For both males and females, the higher infection rate was between $41-50$ years ( 32 cases) and $51-60$ years (29 cases). The lowest occurrence was found in 20-30 years, and after 60 years, the rate of incidents declined as the age advanced (Figure 3 ). The bacterial pathogens did not show significant relation with the environmental condition; the infections caused by them fluctuated over time.

Up to 40 years of age, the infection occurred less, and this might be due to the good immune status of the people. After 40 , the immune system starts to become weak, and this might be responsible for a higher infection rate. 41-60 years old people are generally more active for economic reasons and come in contact with people more. At older ages, people start to stay mostly indoors with very little exposure to outside. So even if the immune system is weakened, they do not have easy access to the infectious bacteria until taking proper health care $(21,22)$. In a previous study, it has been found that people with the age of $25 \geq$ years were less susceptible to respiratory infection compared to those of 60 years old (23).

Acinetobacter spp. $(\mathrm{n}=12)$ were mostly resistant to ceftazidime (100\%), clotrimazole (66.67\%) and amikacin (91.67\%), cefixime (100\%), cefotaxime $(100 \%)$, astrenam (100\%), amoxiclav (75\%) and ceftriaxone (100\%) (Table 1). Most of the Enterobacter spp. showed susceptibility towards all of the antibiotics used during the test. Most of the Klebsiella 
spp. showed susceptibility to 11 antibiotics out of 14 . E. coli showed the highest rate of resistance to 5 antibiotics. Serratia spp. was present in the least number of patients (only 2) and showed a higher degree of susceptibility towards the antibiotics. The tvalue for the percentages of all of the antibiotics have also been measured using the t-test along with their 95\% confidence level.

In different studies, multidrug-resistant bacteria respiratory infections have been found to be so common. E. coli, K. pneumoniae, Enterobacteriaceae $\mathrm{sp}$. showed resistance by producing extendedspectrum beta-lactamases (ESBL) (24). Pseudomonas sp. was also found to be multidrug-resistant due to its capability to produce biofilm (25). Antibiotic resistance is a major medical health concern in these years, and the responsible reasons are misuse of antibiotics, failure to develop new antibiotics, unavailability of alternative drugs, the evolution of bacteria towards resistance (26)

\section{References}

1. Centers for Disease Control and Prevention. 2011. Flu report: weekly summary update. Centers for Disease Control and Prevention, Atlanta, GA. http://www.cdc.gov/flu/weekly/. Accessed 15 April 2011.

2. Cukic V, Hadzic A. The most common detected bacteria in sputum of patients with community acquired pneumonia (CAP) treated in hospital. Med Arch. 2016; 70(5): 364-358. [PMID] [PMCID] [DOI:10.5455/medarh.2016.70.354-358]

3. Ishifuji T, Sando E, Kaneko N, Suzuki M, Kilgore $\mathrm{PE}$, Ariyoshi K, et al. Recurrent pneumonia among Japanese adults: disease burden and risk factors. BMC Pulm Med. 17(1):1-9. [PMID] [PMCID] [DOI:10.1186/s12890-016-0359-1]

4. Kabir MS. Molecular methods for detection of pathogenic viruses of respiratory tract-A review. Asian Pac J Trop Biomed. 2018;1;8(5):237. [DOI:10.4103/2221-1691.233004]

5. Moriyama M, Hugentobler WJ, Iwasaki A. Seasonality of respiratory virus infections. Annu Rev. 2020; 7: 83- 101. [DOI:10.1146/annurevvirology-012420-022445] [PMID]

6. Chowdhary A, Kathuria S, Agarwal K, Meis JF. Recognizing filamentous basidiomycetes as agents of human disease: A review. Med Mycol.

\section{Conclusion}

According to the findings of the current study, the infection rates were higher in male patients than females; this was not dependent on the environmental condition. As most of the bacteria were multidrug-resistant, treating these patients with antibiotics has become a challenge. Without new antibiotics or alternate drugs, treating these patients might be a challenge, resulting in losing many lives.

\section{Acknowledgment}

We are thankful to the laboratory personnel for technical help and the referred authors for the background information needed to explain the study.

\section{Funding}

None.

\section{Conflict of Interest}

Authors have no conflicts of interest.

2014; 52(8):782-97.

[DOI:10.1093/mmy/myu047] [PMID]

7. Chowdhary A, Agarwal K, Meis JF. Filamentous Fungi in Respiratory Infections. What

8. Lies Beyond Aspergillosis and Mucormycosis? PLoS Pathog. 2016; 12(4): e1005491. [PMID] [PMCID] [DOI:10.1371/journal.ppat.1005491]

9. Oliva G, Sahr T, Buchrieser C. The life cycle of L. pneumophila: cellular differentiation is linked to virulence and metabolism. Front Cell Infect Microbiol. 2018; 8:3. [PMID] [PMCID] [DOI:10.3389/fcimb.2018.00003]

10. Samba-Louaka A, Robino E, Cochard T et al. Environmental Mycobacterium avium subsp. paratuberculosis Hosted by Free-Living Amoebae. Front Cell Infect Microbiol. 2018; 8:28. [DOI:10.3389/fcimb.2018.00028] [PMID] [PMCID]

11. Amissah NA, Gryseels S, Tobias NJ, Ravadgar B, Suzuki M, Vandelannoote $\mathrm{K}$, et al. Investigating the Role of Free-living Amoebae as a Reservoir for Mycobacterium ulcerans. PLoS Negl Trop Dis. 2014; 8(9): e3148. [DOI:10.1371/journal.pntd.0003148] [PMID] [PMCID] 
12. Uranga A, España PP, Bilbao A, et al. Duration of Antibiotic Treatment in Community-Acquired Pneumonia: A Multicenter Randomized Clinical Trial. JAMA Intern Med. 2016;176(9):1257-1265. [DOI:10.1001/jamainternmed.2016.3633] [PMID]

13. Lambert AA, Lam JO, Paik JJ, Ugarte-Gil C, Drummond MB, Crowell TA. Risk of CommunityAcquired Pneumonia with Outpatient ProtonPump Inhibitor Therapy: A Systematic Review and Meta-Analysis. PLoS ONE. 2015; 10(6): e0128004. [DOI:10.1371/journal.pone.0128004] [PMID] [PMCID]

14. Munita JM, Arias CA. Mechanisms of Antibiotic Resistance. Microbiol Spectr. 2016;4(2):10. [DOI:10.1128/microbiolspec.VMBF-0016-2015] [PMID] [PMCID]

15. Read AF, Woods RJ. Antibiotic resistance management. Evol Med Public Health. 2014;(1):147. [DOI:10.1093/emph/eou024] [PMID] [PMCID]

16. Ahmed I, Rabbi MB, Sultana S. Antibiotic resistance in Bangladesh: A systematic review. Int. J. of Infect. Dis. 2019; 80: 54-61. [DOI:10.1016/i.ijid.2018.12.017] [PMID]

17. MacFaddin JF. Biochemical tests for identification of medical bacteria. Third edition. Lippincott, Williams and Wilkins, Philadelphia, U.S.A. 2000.

18. Ferraro MJ, Craig WA and Dudley MN. 2001. Performance standards for antimicrobial Susceptibility testing. Eleventh edit. Pennsylvania, USA: NCCLS.

19. CLSI (2020). Performance Standards for Antimicrobial Susceptibility Testing, Twenty-Fifth Informational Supplement in M100-S30. Wayne, PA: Clinical and Laboratory Standards Institute.

20. Kadioglu A, Cuppone AM, Trappetti C et al. SexBased Differences in Susceptibility to Respiratory and Systemic Pneumococcal Disease in Mice. J of Infect Dis. 2011; 204: 1971-9. [DOI:10.1093/infdis/jir657] [PMID]
21. Bhuyan GS, Hossain MA, Sarker SK, Rahat A, Islam MT, Haque TN, et al. Bacterial and viral pathogen spectra of acute respiratory infections in under-5 children in hospital settings in Dhaka city. PLoS ONE. 2017; 12(3): e0174488. [PMID] [PMCID] [DOI:10.1371/journal.pone.0174488]

22. Weyand CM, Yang $Z$ and Goronzy JJ. T-cell aging in rheumatoid arthritis. Curr Opin Rheumatol . 2014; 26(1): 93-100. [PMID] [PMCID] [DOI:10.1097/BOR.0000000000000011]

23. Golomb L, Sagiv A, Pateras IS, Maly A, Krizhanovsky V, Gorgoulis VG, Oren M and BenYehuda A. Age -associated inflammation connects RAS-induced senescence to stem cell dysfunction and epidermal malignancy. Cell Death Differ. 2015; 22(11): 1764-1774. [DOI:10.1038/cdd.2015.21] [PMID] [PMCID]

24. Channappanavar R, Fett C, Mack M, et al. Sexbased differences in susceptibility to Severe Acute Respiratory Syndrome Coronavirus infection. J Immunol 2017;198(10):4046-53. [DOI:10.4049/jimmunol.1601896] [PMID] [PMCID]

25. Borer A, Saidel-Odes L, Riesenberg K, Eskira S, Peled N, Nativ R, Schlaeffer F, Sherf $M$. Attributable mortality rate for carbapenemresistant Klebsiella pneumoniae bacteremia. Infect. Control Hosp. Epidemiol. 2009; 30: 9726.A [DOI:10.1086/605922] [PMID]

26. Clayton W. Hall, Thien-Fah Mah, Molecular mechanisms of biofilm-based antibiotic resistance and tolerance in pathogenic bacteria. FEMS Microbiol Rev. 2017; 14(3): 276-301. [DOI:10.1093/femsre/fux010] [PMID]

27. Van Hecke O, Wang K, Lee JJ, Roberts NW, Butler CC.Implications of antibiotic resistance for patients'recovery fromcommon infections in the community: a systematic review andmetaanalysis.Clin Infect Dis. 2017;65(3):371-382. [DOI:10.1093/cid/cix233] [PMID] [PMCID] 